\title{
Abbreviations and Conventions
}

In the body of the volume, citations of a multi-volume text in parentheses without any additional abbreviation, for example, "(2:179)," refer to the following edition, which is designated by GS whenever it is required: Walter Benjamin, Gesammelte Schriften, 7 vols., ed. Rolf Tiedemann and Hermann Schweppenhäuser (Frankfurt am Main: Suhrkamp, 1972-91). Citations to a single-volume text in parentheses, for example, “(217)," refer to this volume. The following abbreviations are used throughout the volume:

GB Walter Benjamin. Gesammelte Briefe. 6 vols. Edited by Christoph Gödde and Henri Lonitz. Frankfurt am Main: Suhrkamp, 1995-2000.

$K G A$ Walter Benjamin. Werke und Nachlaß: Kritische Gesamtausgabe. 21 vols. planned, 9 vols. to date. Edited by Christoph Gödde and Henri Lonitz in association with the Walter Benjamin Archive. Frankfurt am Main: Suhrkamp, 2008- . (References to a volume of this edition also include the names of its individual editors.)

$T B$ Gershom Scholem. Tagebücher: Nebst Aufsätzen und Entwürfen bis 1923. 2 vols. Edited by Karlfried Gründer, Herbert KoppOberstebrink, and Friedrich Niewöhner in association with Karl Grözinger. Frankurt am Main: Jüdischer Verlag, 1995-2000.

Scholem Arc Gershom Scholem Archive, National Library of Israel, Jerusalem. Scholem Coll Gershom Scholem Collection, National Library of Israel, Jerusalem. WBA Walter Benjamin Archive, Akademie der Künste, Berlin. 
All translations throughout the volume are new; references to existing translations are given whenever available for the convenience of Englishspeaking readers. When references are made to existing translations of Benjamin's writings not included in this volume, the following abbreviations are used:

Walter Benjamin. Correspondence. Translated by Manfred Jacobsen and Evelyn Jacobsen. Chicago: University of Chicago Press, 1994. Walter Benjamin. Origin of the German Trauerspiel. Translated by Howard Eiland. Cambridge, MA: Harvard University Press, 2019. SW Walter Benjamin. Selected Writings. 4 vols. Edited by Michael Jennings, Howard Eiland, et al. Cambridge, MA: Harvard University Press, 1996-2000.

Citations without abbreviations in the appendices to the volume refer to the original pagination of the relevant texts. References to Kant's writings throughout the volume use the following abbreviations:

Aka

Immanuel Kant. Gesammelte Schriften. 29 vols. to date. Edited by Königlich-Preußische (later, Deutsche) Akademie der Wissenschaften. Berlin: Reimer; later, Walter de Gruyter, 1900- .

A Critique of Pure Reason ( 1781 edition)

$B$ Critique of Pure Reason (1787 edition)

For the Notes and Fragments, the following editorial conventions are used:

Single underline in the manuscript $=$ italics

Double underline in the manuscript $=$ underlined italics

Square brackets in the manuscript $=\{\}$

Editorial insertions $=<>$

In the Afterword, brackets in the original are indicated with \{\} . 
Toward the Critique of Violence 
This page intentionally left blank 